\title{
Retinal Vascular Signs in Diabetes and Hypertension - Review
}

\begin{abstract}
The retinal vasculature is a unique site where the microcirculation can be noninvasively imaged in vivo. This presents an opportunity to study otherwise inaccessible structural features of the microcirculation. Recently, a number of population-based studies have developed quantitative methods of measuring these retinal signs, and investigated how these signs relate to metabolic disorders such as diabetes, hypertension, obesity, and metabolic syndrome. These studies have reported fairly consistent associations of retinopathy lesions, arteriolar narrowing and venular dilation with these metabolic disorders, suggesting a microvascular component in either the pathogenesis or manifestation of these disorders. Further, several of these signs have been associated with future risk of cardiovascular outcomes, such as coronary heart disease and stroke, independently of traditional risk factors. This review will examine in detail the evidence linking retinal vascular signs with metabolic disorders and discuss their implications for research and clinical practice. (Arq Bras Endocrinol Metab 2007;51/2:352-362)
\end{abstract}

Keywords: Diabetes mellitus; Microcirculation; Retinal vasculature; Cardiovascular disease

\section{RESUMO}

\section{Sinais Vasculares Retinianos no Diabetes e Hipertensão.}

A vasculatura retiniana apresenta uma oportunidade única de observação não-invasiva da microcirculação e de suas estruturas in vivo. Recentemente, uma série de estudos populacionais desenvolveu métodos quantitativos de observação destes sinais retinianos e suas relações com distúrbios metabólicos, tais como diabetes, obesidade, hipertensão arterial e síndrome metabólica. Esses estudos demonstraram associações das lesões retinianas, entre elas estreitamento arteriolar e dilatação venular, com essas alterações metabólicas, sugerindo um componente microvascular na patogênese ou na manifestação destes distúrbios. Ainda, vários destes sinais foram associados com risco de doença cardiovascular, tais como doença arterial coronariana e acidente vascular cerebral independente dos fatores de risco clássicos. Esta revisão discute em detalhes as evidências entre os sinais retinianos e os distúrbios metabólicos e suas possíveis implicações na pesquisa e na prática clínica. (Arq Bras Endocrinol Metab 2007;51/2:352-362)

Descritores: Diabetes mellitus; Microcirculação; Vasculatura retiniana; Doença cardiovascular

$T^{\text {sing }}$ HE MICROCIRCULATION REPRESENTS the bulk of the circulatory system, yet its role in vascular pathology is poorly understood. In part this is due to difficulties in imaging the microcirculation in vivo. The retinal vasculature is a unique site where the microcirculatory vessels are arrayed in a two-dimensional plane amenable to noninvasive high-resolution photography and subsequent in-depth analysis. In the past decade methods have

\section{revisão}

\author{
Gerald LieW \\ JIE JIN WANG
}

Centre for Vision Research, Department of Ophthalmology (Westmead Hospital), the Westmead Millennium Institute, University of Sydney, and the Vision Co-operative Research Centre, Sydney, Australia.
Recebido em 12/01/07

Aceito em 17/01/07

Arq Bras Endocrinol Metab 2007;51/2 
been developed which take advantage of advances in digital photography and image processing software to extract a wealth of data on microvascular structure from retinal images. Recent population-based studies have documented the subtle retinal vascular changes that occur in metabolic disorders such as diabetes, hypertension, obesity and metabolic syndrome, providing new understanding of the microvascular involvement in these disorders. It has now become evident that these retinal vascular changes might be markers of early, pre-clinical stages of these metabolic disorders and may predict their clinical onset. This review provides an update on recent epidemiological studies investigating the relationship of retinal vascular changes in diabetes, hypertension, obesity and metabolic syndrome, and discusses the research and clinical implications of these new findings. Table 1 summarizes key population-based epidemiologic findings to date.

\section{RETINAL VASCULAR SIGNS AND DIABETES}

\section{Retinopathy in diabetes}

The primary retinal vascular complication in diabetes, diabetic retinopathy, is well described and familiar to most clinicians. Diabetic retinopathy is the leading cause of blindness among working age adults and as such represents a condition of important public health and economic consequence (1). A number of classification systems to grade severity of diabetic retinopathy are currently in use - for research purposes, the Early Treatment Diabetic Retinopathy Study (ETDRS) 100 level scale (or slight modifications) are widely used (2), whereas for clinical practice, a new international 5stage classification (none, mild, moderate, severe and proliferative) has been proposed and is gaining wide acceptance (3).

There is strong evidence that longer duration of diabetes, poorer control of blood glucose, and elevated blood pressure are the major factors responsible for the onset and progression of diabetic retinopathy. The Wisconsin Epidemiologic Study of Diabetic Retinopathy (WESDR), a population-based cohort study of diabetes, showed that in persons with type 1 diabetes, the prevalence of diabetic retinopathy ranged from $17 \%$ in those with diabetes for less than 5 years to almost $100 \%$ in those with diabetes for over 15 years (4). The corresponding figures in persons with type 2 diabetes were $29 \%$ and $78 \%$ (5). The importance of good glycemic control for delaying the development and progression of diabetic retinopathy has been confirmed in both epidemiological studies (6) and two landmark clinical trials, the Diabetes Control and Complications Trial (DCCT) for type 1 diabetes (7), and the UK Prospective Diabetes Study (UKPDS) for type 2 diabetes patients (8). The UKPDS has further shown the value of tight blood pressure control in delaying the development of diabetic retinopathy complications and well as other microvascular endpoints $(9,10)$.

Other potential risk factors for diabetic retinopathy include dyslipidemia, obesity, systemic vascular inflammation and endothelial dysfunction $(11,12)$. In the WESDR study $(13)$ and the ETDRS trial (14), participants with dyslipidemia were more likely to have or develop hard exudates, while the Fenofibrate Intervention and Event Lowering in Diabetes Study (15) indicated that lipid lowering therapy might reduce retinopathy requiring laser treatment. There is some evidence that markers of obesity such as high body mass index and greater waist-to-hip ratio are correlated with increased risk of diabetic retinopathy from the DCCT (16), the EURODIAB Prospective Complications studies (17), Diabetes Incidence Study (18), the World Health Organisation Multinational Study of Vascular Disease in Diabetes (19) (referring to type 1 diabetes), as well as the UKPDS (20) and Hoorn Study (in type 2 diabetes) (12). The Hoorn study additionally reported an association of systemic markers of inflammation and endothelial dysfunction with diabetic retinopathy (12).

Diabetes prevalence appears to vary among different ethnic groups, suggesting that the prevalence of diabetic retinopathy may also vary by ethnicity (21). The few studies that have reported on diabetic retinopathy in non-white groups suggest that AfricanAmericans and Hispanics have higher prevalence rates than whites (22-25). Recently, the Multi-Ethnic Study of Atherosclerosis (MESA) study reported diabetic retinopathy prevalence rates among subjects with diabetes: $36.7 \%$ in African-Americans, 37.4\% in Hispanics, $24.8 \%$ in whites, and $25.7 \%$ in Chinese-Americans (21). Differences in risk factors such as diabetes duration, glycemic control and hypertension appear to explain the higher prevalence of diabetic retinopathy in African-Americans, but cannot explain the similar prevalence observed in Hispanics, suggesting a role for other as yet unidentified genetic or environmental factors (22-25).

Retinopathy lesions may be markers of diabetic microvascular complications in other vascular beds. In the ARIC study, persons with type 2 diabetes and retinopathy lesions had 4 -fold higher risk of incident 
Table 1. Cross-sectional and predictive associations of retinal vascular signs.

\begin{tabular}{|c|c|c|c|c|}
\hline Retinal vascular sign & Is associated with & $\begin{array}{l}\text { May independently pre- } \\
\text { dict the risk of incident }\end{array}$ & $\begin{array}{l}\text { Over a period } \\
\text { of (years) }\end{array}$ & $\begin{array}{l}\text { Magnitude of risk } \\
\text { increase (OR or RR) }\end{array}$ \\
\hline \multirow[t]{9}{*}{ Retinopathy } & $\begin{array}{l}\text { Diabetes/Hyperglycemia DCCT } \\
\text { (7), UKPDS (8), WESDR (4-6) }\end{array}$ & $\begin{array}{l}\text { Stroke } \\
\text { ARIC }(53,90), \text { BMES }(66)\end{array}$ & 3 & $\begin{array}{l}2-3 \text { fold } \\
\text { (up to } 20 \text { fold if concurrent } \\
\text { with cerebral WMLs) }(90)\end{array}$ \\
\hline & $\begin{array}{l}\text { Current elevated blood pressure } \\
\text { ARIC (76), BDES (74), BMES } \\
(33,75), \text { CHS }(69) \text {, Funagata (77), } \\
\text { Hoorn (91) }\end{array}$ & $\begin{array}{l}\text { Coronary heart disease } \\
\text { ARIC (73) }\end{array}$ & 3 & 2-fold in women only \\
\hline & $\begin{array}{l}\text { Metabolic Syndrome } \\
\text { MESA (46) }\end{array}$ & $\begin{array}{l}\text { Congestive cardiac failure } \\
\text { ARIC (26) }\end{array}$ & 3 & 2-3 fold \\
\hline & $\begin{array}{l}\text { Impaired Glucose Tolerance } \\
\text { AusDiab (34) }\end{array}$ & $\begin{array}{l}\text { Diabetes } \\
\text { ARIC (35) }\end{array}$ & 3 & $\begin{array}{l}2 \text { fold only if positive family } \\
\text { history of diabetes, else no } \\
\text { increased risk }\end{array}$ \\
\hline & $\begin{array}{l}\text { Hyperlipidemia } \\
\text { ETDRS (14), Hoorn }(91,92) \text {, } \\
\text { Fenofibrate Trial }(15), \text { WESDR } \\
\text { (13) }\end{array}$ & $\begin{array}{l}\text { Coronary heart disease } \\
\text { and stroke mortality } \\
\text { BDES (67), Hoorn (93) }\end{array}$ & 10,11 & 2-fold \\
\hline & $\begin{array}{l}\text { Obesity } \\
\text { DCCT (16), Hoorn }(91,92) \text {, Funa- } \\
\text { gata (77), UKPDS }(20)\end{array}$ & & & \\
\hline & $\begin{array}{l}\text { Systemic inflammatory markers } \\
\text { Hoorn (11) }\end{array}$ & In Diabetes & & \\
\hline & $\begin{array}{l}\text { Endothelial dysfunction markers } \\
\text { Hoorn (11) }\end{array}$ & $\begin{array}{l}\text { Type } 1 \\
\text { Risk of angina, stroke, } \\
\text { heart mortality, myocardial } \\
\text { infarction, nephropathy, } \\
\text { lower limb amputation } \\
\text { WESDR (27-30) }\end{array}$ & 3 & $1.3-2.0$ fold \\
\hline & $\begin{array}{l}\text { Carotid Plaque and IMT } \\
\text { ARIC (22), CHS (63) }\end{array}$ & $\begin{array}{l}\text { Type } 2 \\
\text { Congestive cardiac failure } \\
\text { ARIC (26) }\end{array}$ & 20 & 4-fold \\
\hline
\end{tabular}

MRI-defined cerebral infarct

ARIC (79)

Cognitive impairment ARIC (61)

Renal dysfunction

ARIC (60), CHS (62)

\section{In Diabetes \\ Neuropathy \\ AusDiab (94)}

Carotid stiffness and IMT

Chennai (95)

\begin{tabular}{|c|c|c|c|c|}
\hline & $\begin{array}{l}\text { Hyperhomcysteinemia } \\
\text { Hoorn (96) }\end{array}$ & & & \\
\hline \multirow[t]{4}{*}{ Focal arteriolar narrowing } & $\begin{array}{l}\text { Severity of current elevated } \\
\text { blood pressure } \\
\text { ARIC }(46,68), \text { CHS }(69)\end{array}$ & $\begin{array}{l}\text { Hypertension } \\
\text { ARIC (71), BMES (97) }\end{array}$ & 3,5 & 1.6-fold \\
\hline & $\begin{array}{l}\text { Obesity } \\
\text { ARIC (46) }\end{array}$ & $\begin{array}{l}\text { Coronary heart disease } \\
\text { CPP (73) }\end{array}$ & 8 & 3-fold in men \\
\hline & $\begin{array}{l}\text { Metabolic syndrome } \\
\text { ARIC (46) }\end{array}$ & $\begin{array}{l}\text { Coronary heart disease } \\
\text { and stroke deaths } \\
\text { BDES (67) }\end{array}$ & 10 & $\begin{array}{l}2 \text {-fold in those } 43-74 \text { years } \\
\text { of age }\end{array}$ \\
\hline & $\begin{array}{l}\text { MRI-defined cerebral infarcts } \\
\text { ARIC (79) }\end{array}$ & & & \\
\hline
\end{tabular}


Table 1. Continuação

\begin{tabular}{|c|c|c|c|c|}
\hline & & $\begin{array}{l}\text { In Diabetes } \\
\text { Type } 1 \\
\text { Lower limb amputation } \\
\text { WESDR (28) }\end{array}$ & 20 & 3.6-fold \\
\hline \multirow[t]{8}{*}{ Arteriovenous nicking } & $\begin{array}{l}\text { Current elevated blood pressure } \\
\text { ARIC }(46,76), \text { BDES (74), BMES } \\
\text { (75), CHS (69), Funagata (77) }\end{array}$ & & & \\
\hline & $\begin{array}{l}\text { Past elevated blood pressure } \\
\text { ARIC (68), CHS (69) }\end{array}$ & & & \\
\hline & $\begin{array}{l}\text { Obesity } \\
\text { ARIC (46) }\end{array}$ & & & \\
\hline & $\begin{array}{l}\text { Low HDL } \\
\text { ARIC (46) }\end{array}$ & & & \\
\hline & $\begin{array}{l}\text { Systemic inflammatory markers } \\
\text { ARIC (78) }\end{array}$ & & & \\
\hline & $\begin{array}{l}\text { Endothelial dysfunction markers } \\
\text { ARIC (78) }\end{array}$ & & & \\
\hline & $\begin{array}{l}\text { MRI-defined cerebral infarct } \\
\text { ARIC (79) }\end{array}$ & & & \\
\hline & $\begin{array}{l}\text { Renal dysfunction } \\
\text { ARIC (60) }\end{array}$ & & & \\
\hline \multirow[t]{10}{*}{ Venular dilation } & $\begin{array}{l}\text { Systemic inflammatory markers } \\
\text { BDES (44), MESA (45), Rotterdam } \\
(43)\end{array}$ & $\begin{array}{l}\text { Stroke } \\
\text { CHS (50), Rotterdam (52) }\end{array}$ & $5,8.5$ & 2-fold \\
\hline & $\begin{array}{l}\text { Endothelial dysfunction } \\
\text { MESA (45) }\end{array}$ & $\begin{array}{l}\text { Coronary heart disease } \\
\text { BMES (51), CHS (50) }\end{array}$ & 9,5 & 3-fold \\
\hline & $\begin{array}{l}\text { Hyperglycemia } \\
\text { BDES (44), MESA (45), Rotterdam } \\
\text { (43) }\end{array}$ & $\begin{array}{l}\text { Progression of cerebral } \\
\text { small vessel disease Rot- } \\
\text { terdam (40) }\end{array}$ & 3 & - \\
\hline & $\begin{array}{l}\text { Smoking } \\
\text { MESA (45) }\end{array}$ & $\begin{array}{l}\text { Diabetes } \\
\text { Rotterdam (39) }\end{array}$ & 8.5 & 1.5-fold \\
\hline & $\begin{array}{l}\text { Higher triglycerides } \\
\text { MESA (45) }\end{array}$ & $\begin{array}{l}\text { Obesity } \\
\text { BMES (47) }\end{array}$ & 5 & 2-fold \\
\hline & $\begin{array}{l}\text { Obesity } \\
\text { BMES (47), MESA (45), Rotter- } \\
\text { dam (43), SCORM (48) }\end{array}$ & & & \\
\hline & $\begin{array}{l}\text { Carotid IMT } \\
\text { Hoorn (98) }\end{array}$ & & & \\
\hline & In Diabetes & $\begin{array}{l}\text { In Diabetes } \\
\text { Type } 1 \\
\text { Incidence of diabetic } \\
\text { nephropathy (proteinuria, } \\
\text { raised creatinine) } \\
\text { WESDR (99) }\end{array}$ & 16 & 1.5-fold \\
\hline & $\begin{array}{l}\text { Retinopathy severity } \\
\text { WESDR }(100)\end{array}$ & $\begin{array}{l}\text { Type } 2 \\
\text { Stroke } \\
\text { CHS (50) }\end{array}$ & 5 & $\begin{array}{l}\text { 2-fold (nonsignficant } \\
\text { because of small numbers) }\end{array}$ \\
\hline & & $\begin{array}{l}\text { Coronary heart disease } \\
\text { (CHS50) }\end{array}$ & 5 & 4-fold \\
\hline Narrower arterioles & $\begin{array}{l}\text { Current elevated blood pressure } \\
\text { ARIC }(46,68,76), \text { BDES (74), BMES } \\
\text { (75), Funagata (77), MESA (45), } \\
\text { Rotterdam (43) }\end{array}$ & $\begin{array}{l}\text { Hypertension } \\
\text { ARIC (71), BDES (84), } \\
\text { BMES (72), Rotterdam (85) }\end{array}$ & $3,10,5,7$ & 2-3-fold \\
\hline
\end{tabular}


Table 1. continuação

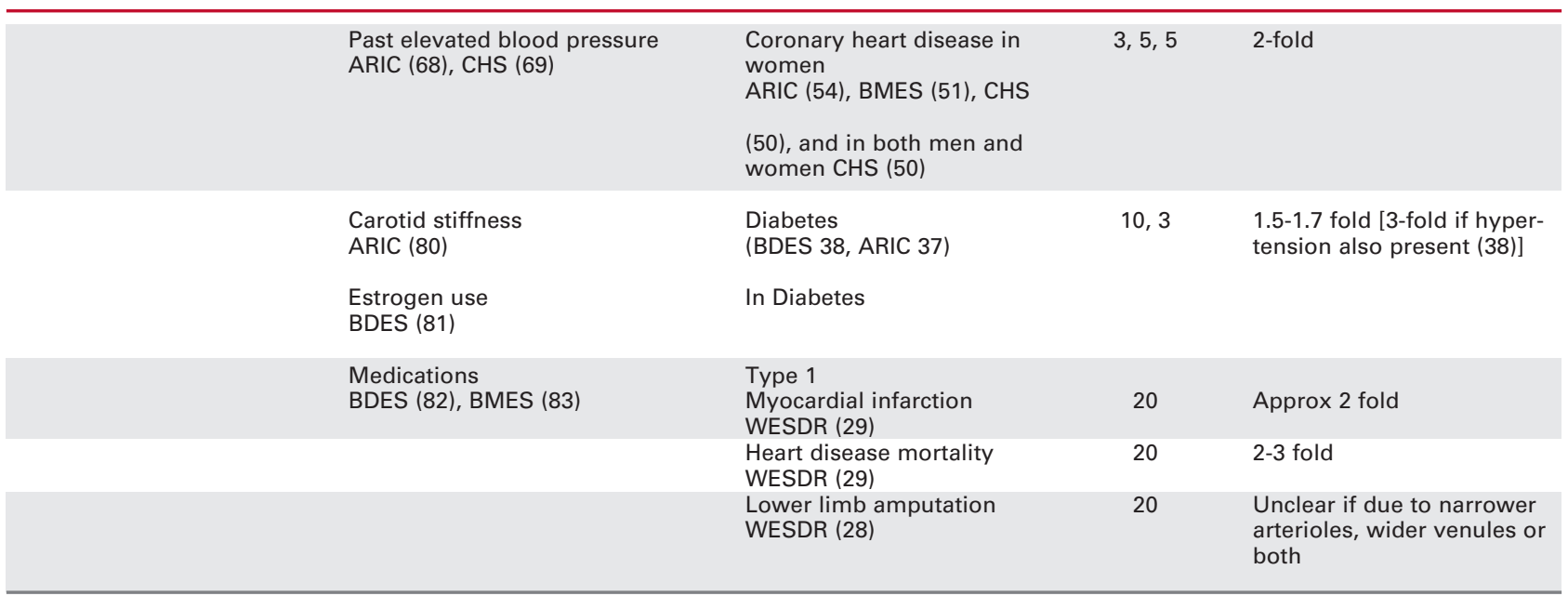

ARIC: Atherosclerosis Risk In Communities Study; BDES: Beaver Dam Eye Study; BMES: Blue Mountains Eye Study; Chennai: Chennai Urban Rural Epidemiology Study; CHS: Cardiovascular Health Study; DCCT: Diabetes Control and Complications Trial; Fenofibrate: Fenofibrate Intervention and Event Lowering in Diabetes study; Hoorn: Hoorn Study; MESA: Multi-Ethnic Study of Atherosclerosis; Rotterdam: Rotterdam Study; WESDR: Wisconsin Epidemiologic Study of Diabetic Retinopathy; SCORM: Singapore Cohort Study of the Risk Factors for Myopia

OR, RR: Odds ratio, Relative Risk

WML: White Matter Lesions

IMT: Intima-Media Thickness

congestive cardiac failure, after adjusting for other risk factors (26). The WESDR study showed that in type 1 diabetes, proliferative retinopathy was an independent marker of increased risk of stroke, angina, myocardial infarction, nephropathy, lower limb amputation and mortality (27-30). In persons with type 1 diabetes, the WESDR also showed that other retinal vascular abnormalities also predicted risk of peripheral arterial disease, with small arteriole-tovenule ratio (a measure of either narrower arterioles relative to venules or wider venules relative to arterioles) and focal arteriolar narrowing independently associated with 2-3 fold higher risk of lower limb amputation (28). Small AVR was also associated with approximately twice the risk of myocardial infarction and mortality from heart disease (29).

\section{Retinopathy without diabetes}

Interestingly, retinopathy lesions can be found in $10-14 \%$ of individuals over 40 years without overt diabetes, and results from the Beaver Dam Eye Study (BDES) (31) and Blue Mountains Eye Study (BMES) (32) show that on average, $1.2-1.8 \%$ of persons in this age group without diabetes develop retinopathy lesions per year. Such 'nondiabetic' lesions appear to be transient entities, with $72 \%$ regressing over 5 years (32). Their pathogenesis is as yet unclear, although hypertension and elevated plasma glucose (below the diabetic threshold) is believed to play a role $(33,34)$. It might be expected that the presence of retinopathy lesions in persons without diabetes would signal increased risk of overt diabetes, but the data from population-based cohort studies do not support this postulate. In the Atherosclerosis Risk in Communities (ARIC) study, retinopathy lesions were not associated with 3 -year incident diabetes except in the subgroup of persons with a positive family history of diabetes, where risk was increased 2-fold (35). Similarly, in the BMES, retinopathy lesions did not confer increased risk of diabetes in 5 years $(32)$.

\section{Venular dilation and diabetes, metabolic disorders}

Venular dilation has long been recognized as an early change in diabetic retinopathy (36). Recently, it has become possible to quantify variations in venular calibre between individuals using specialized software, and a 
number of intriguing associations have emerged. Wider venules relative to arterioles, as represented by smaller AVR, may predict the development of incident diabetes. The ARIC (37) and BDES (38) have reported 50-70\% higher risk of incident type 2 diabetes with small AVR, while in those with hypertension, the risk of incident diabetes with small AVR is increased further to over 3 -fold (38). The Rotterdam study examined venular calibre and found wider venules associated with incident impaired fasting glucose and type 2 diabetes (39). These findings shed light on the early microcirculatory changes that occur with diabetic retinopathy, and suggest that retinal photography may potentially help identify persons at risk of developing diabetic complications. The underlying causes of this microvascular change remain unclear, although it has been suggested that venular dilation may be related to retinal hypoxia or venous stasis (40). Experimentally induced hyperglycemia in persons without diabetes can cause venular dilation, suggesting a direct effect of glucose on venular calibre (41). Other influences on venular calibre may include reduced vascular reactivity associated with inflammatory processes and endothelial dysfunction, which occur in impaired glucose tolerance (42). The Rotterdam, (43), BDES (44), and MESA (45) studies provide further evidence supporting a link between venular dilation and inflammation and endothelial dysfunction. These studies reported consistent associations between wider venular caliber and markers of systemic inflammation [high sensitivity Creactive protein (hsCRP), interleukin-6, higher leukocyte count, higher erythrocyte sedimentation rate, plasma fibrinogen $\}$ and endothelial dysfunction [soluble intercellular adhesion molecule-1 (sICAM-1) and plasminoegen activator inhibitor (PAI-1)] among older persons with and without diabetes. The ARIC study has also reported a cross-sectional association between wider venular calibre and the metabolic syndrome (46), as well as with some components of the metabolic syndrome (large waist circumference, high triglycerides levels, hyperglycemia) but not others [high blood pressure and low high-density lipoprotein (HDL) cholesterol] (46). The Rotterdam study and BMES reported cross-sectional associations of wider venular calibre with high body mass index $(43,47)$, with the BMES additionally reporting a longitudinal relationship whereby persons with wider venular calibre (in the highest quintile) at baseline were $60-70 \%$ more likely to become obese or gain weight over 5 -years than persons with venular calibre in the lowest quintile (47). The same cross-sectional relationship between wider venules and obesity has been demonstrated in young children in whom the confounding effects of age, hypertension, and other co-mor- bidities are of less concern (48). These associations emphasize the close links between retinal venular calibre and metabolic disturbances, and point to a role for impaired microvascular function in the pathology of metabolic syndrome. The exact mechanisms linking these associations are not clear, but may be related to systemic inflammation, endothelial dysfunction, increased blood volume or hormonal changes that occur with metabolic disturbances (49).

Venular calibre may also convey prognostic information on cardiovascular risk independent of traditional risk factors such as hypertension, dyslipidemia, smoking and obesity. In the Cardiovascular Health Study (CHS), persons with diabetes who also had wider venules were 4 times more likely to have an incident coronary heart disease event in the next 5 years, independently of risk factors $(50)$. There was also a suggestion that wider venules in diabetes were associated with at least twice the risk of incident stroke in the same time period, although this association was non-significant due to limited numbers of stroke events (50). In persons without diabetes, wider venules were associated with $80 \%$ higher risk of incident coronary heart disease, and non-significantly 60\% higher risk of incident stroke, due to small number of events (50). The BMES has also reported an association of wider venules with increased risk of coronary heart disease in men and women between 49-75 years of age inclusive (51). An independent association between wider venules and incident stroke and cerebral infarction (52), as well as progression of cerebral small vessel disease (40), was also reported from the Rotterdam study. These findings confirm and extend earlier reports from the ARIC study that small AVR — in this case most likely representing wider venules relative to arterioles independently predicted the risk of coronary heart disease (in women) and stroke in both men and women with and without diabetes $(53,54)$.

\section{RETINAL VASCULAR CHANGES, HYPERTENSION AND CARDIOVASCULAR DISEASE}

Recognition that a careful clinical examination of the retinal vasculature provides information on hypertension-related tissue damage dates back at least a century when Marcus Gunn described the classic retinal arteriolar changes that occur in hypertension (55). These changes include retinopathy lesions (microaneuryms, hemorrhages and soft exudates, cotton wool spots), focal arteriolar narrowing, arterio-venous nicking, and generalized arteriolar narrowing. As described earlier, many of the same population-based studies that con- 
firmed and quantified clinical impressions of a strong relationship between retinal vascular changes and diabetes have also established that hypertension exerts a profound effect on the retinal vasculature. Virtually all studies to date have confirmed the strong, consistent, gradient association between the retinal vascular changes with increasing levels of blood pressure in both adults and children $(56,57)$. Between $8-14 \%$ of nondiabetic populations have signs of one or more of these hypertensive retinal vascular lesions (56).

\section{Retinopathy and hypertension}

As described earlier, retinopathy lesions are common in the non-diabetic population. The BDES reported a prevalence of $7.8 \%$ in older adults (58) without diabetes, while the BMES reported a prevalence of $9.8 \%$ (33). Risk factors for retinopathy lesions in persons without diabetes included blood pressure and advancing age, although blood pressure appeared to explain less than half the prevalence observed (33) and was not associated with incident lesions over a 5 -year period (32).

There appears to be racial differences in the prevalence of retinopathy lesions in the non-diabetic population, with the lesions twice as common in African-Americans in the ARIC study compared to whites (59). The higher burden of hypertension in the African-American population appears to explain much of this excess (59). The ARIC study also reported cross-sectional associations of retinopathy lesions with concurrent renal dysfunction (60) and cognitive impairment as measured using a series of neuropsychological tests (61). The CHS has also reported the same association of retinopathy with concurrent renal dysfunction (62). These results provide evidence that retinopathy lesions, even in persons without diabetes, may reflect the existence of severe microvascular disease in other systemic vascular beds which contribute to diseases in other organs.

Retinopathy lesions in persons without diabetes also appear to be markers of non-diabetic related systemic microvascular pathology (49). Carotid artery thickening is associated with retinopathy lesions (63) in the absence of diabetes. In the whole cohort of the Atherosclerosis Risk in Communities (ARIC) Study (i.e. persons with and without diabetes), the presence of retinopathy predicted 2-3 fold higher risk of ischemic stroke (53), while the joint presence of retinopathy lesions and cerebral white matter lesions on MRI increases the risk of stroke by almost 20-fold (64). These associations were independent of the effects of age, gender, hypertension, diabetes, smoking, dyslipi- demia, and other cardiovascular risk factors. In the same population, retinopathy lesions were found to independently predict the risk of congestive heart failure (2-fold higher risk) (65). In the BMES cohort (66), retinopathy lesions in persons without diabetes also predicted almost 2-fold higher risk of stroke and stroke mortality, while in the BDES (67) retinopathy lesions in persons without diabetes was related to 2 -fold higher risk of cardiovascular mortality.

\section{Focal arteriolar narrowing}

Defined as localized narrowing of the retinal arterioles, this lesion appears to be a transient marker for the severity of concurrent hypertension $(56,68,69)$. Prolonged exposure to elevated blood pressure leads to vasospasm and later, intimal thickening, medial hyperplasia and arteriosclerosis manifesting as either generalized or focal arteriolar narrowing (70). In the ARIC (71) study, the presence of focal arteriolar narrowing was associated with $60 \%$ higher risk of incident hypertension 3 years later. The BMES (72) reported findings of similar magnitude, although the results were not statistically significant. The WESDR reported that in persons with type 1 diabetes, focal narrowing predicted 3.5-fold increased risk of low limb amputation, after adjusting for other risk factors (28). An analysis of data from the Lipid Research Clinic's Coronary Primary Prevention Trial suggested that focal narrowing may predict incident coronary heart disease in men, but these findings have not been confirmed elsewhere (73).

\section{Arteriovenous nicking (or nipping)}

Arteriovenous nicking is associated with both present and past blood pressure $(56,68,69,74-77)$, as well as markers of metabolic disturbance such as low HDL, obesity (46), inflammation and endothelial dysfunction (78). These associations suggest it may serve as a lasting marker of cumulative microvascular damage from chronically elevated blood pressure and some metabolic disorders. This view is reinforced by reports from the ARIC study that arteriovenous nicking is associated with MRI evidence of cerebral infarcts (79) and renal dysfunction (60). However, arteriovenous nicking does not appear related to risk of incident cardiovascular disease outcomes such as stroke and coronary heart disease, after adjustment for traditional risk factors (56).

\section{Narrower arterioles}

Generalized arteriolar narrowing is one of the most evident clinical signs discernable on direct ophthalmoscopy, and has long been interpreted as evidence of chronically elevated blood pressure, both past and pre- 
sent $(55,56)$. Recently, it has become possible to quantify the degree of arteriolar narrowing using computer-assisted methods and sophisticated image processing algorithms (76). These methods have been applied to large population-based studies to clarify the relationship of arteriolar narrowing with hypertension and cardiovascular disease. Strong and consistent associations with a dose-response pattern have been reported between narrower arterioles and higher concurrent blood pressure from 7 populations - ARIC $(68,76)$, CHS (69), BDES (74), BMES (75), Rotterdam (43), Funagata (77), and MESA studies (45). Other cross-sectional relationships that have been reported for narrower arteriolar calibre include increased carotid stiffness (ARIC) (80), estrogen therapy use (BDES) (81), and medication use [e.g. topical glaucoma medications in BDES (82), lower or nonaspirin use in BMES (83)].

In the BDES, narrower arterioles prospectively predicted a 3 -fold higher risk of incident hypertension over 10 years, independently of other risk factors, which attenuated to a 2 -fold high risk after adjustment for baseline systolic and diastolic blood pressure (84). The same association, of similar magnitude, has been reported from the ARIC study (71), the BMES (72), and the Rotterdam study (85). There was some suggestion from the Rotterdam study that narrower venules may also be predictive of incident hypertension, but this was subsequently shown to be a confounding result by arteriolar calibre that is highly correlated with both hypertension and venular calibre $(86,87)$. In the ARIC study, small AVR was associated with 2 -fold higher risk of incident coronary heart disease in women (54), findings confirmed from the BMES which additionally showed the relationship to be due to both arteriolar narrowing and venular dilation (51). Recently, the CHS reported that narrower arterioles also predicted a similar magnitude of incident coronary heart disease in both men and women (50). Narrower arteriolar calibre does not appear to be related to risk of stroke $(50,52)$. These results highlight the contribution of microvascular disease to risk of coronary heart disease, and suggest that measurement of retinal vessel calibres may be useful adjuncts for cardiovascular risk prediction.

\section{SUMMARY AND FUTURE RESEARCH}

Retinal photography offers a unique opportunity to study in detail structural features of the in vivo microcirculation than are otherwise inaccessible to imaging.
Microvascular abnormalities and vessel calibres can be accurately and reliably quantified from high-resolution retinal images. Recently, several large population-based studies have reported strong and consistent associations of retinal vascular signs with metabolic disturbances such as diabetes, hypertension, obesity, and metabolic syndrome, pointing to a microvascular role in these disorders. Prospective associations between retinal vascular signs, particularly venular dilation, and incident cardiovascular outcomes in persons with and without diabetes have also been reported, suggesting that these signs may prove useful adjuncts to cardiovascular risk prediction using traditional risk factors. Nonetheless, several important areas remain inadequately explored. Firstly, the pathophysiological processes leading to retinal vascular signs such as venular dilation, and how these processes link the retinal microcirculation with cardiovascular disease elsewhere, are not clear. Much experimental work is required to elucidate these relationships. Secondly, demonstration of prospective associations with incident cardiovascular outcomes is not sufficient for translation into clinical practice. To be clinically useful, retinal signs must demonstrate additional prognostic information for cardiovascular risk prediction, over and above the contributions from traditional risk factors. Studies examining this issue are currently underway. Finally, the role of genetics in determining retinal vascular structure warrants further study. Much of the variability in arteriolar and venular calibres is believed to be related to genetic factors $(88,89)$ and a number of candidate genes have been postulated (88), but to date no strong evidence implicating specific genes is available. This information will be valuable in revealing the microvascular pathophysiology of hypertension and cardiovascular disease, and to answering the questions of whether retinal vascular signs represent a summary measure of genetic and environmental exposures and live up to their promise as valuable new cardiovascular risk markers.

\section{ACKNOWLEDGEMENTS}

Supported by the Australian National Health \& Medical Research Council, Canberra Australia (Grants No 153948 and 302068)

\section{REFERENCES}

1. Congdon NG, Friedman DS, Lietman T. Important causes of visual impairment in the world today. JAMA 2003;290:2057-60.

2. Klein R, Klein BE, Magli YL, Brothers RJ, Meuer SM, Moss SE, et al. An alternative method of grading diabetic retinopathy. Ophthalmology 1986;93:1183-7. 
3. Wilkinson $\mathrm{CP}$, Ferris $\mathrm{FL}$, III, Klein RE, Lee PP, Agardh CD, Davis $M$, et al. Proposed international clinical diabetic retinopathy and diabetic macular edema disease severity scales. Ophthalmology 2003;110:1677-82.

4. Klein R, Klein BE, Moss SE, Davis MD, DeMets DL. The Wisconsin epidemiologic study of diabetic retinopathy. II. Prevalence and risk of diabetic retinopathy when age at diagnosis is less than 30 years. Arch Ophthalmol 1984;102:520-6.

5. Klein R, Klein BE, Moss SE, Davis MD, DeMets DL. The Wisconsin epidemiologic study of diabetic retinopathy. III. Prevalence and risk of diabetic retinopathy when age at diagnosis is 30 or more years. Arch Ophthalmol 1984;102:527-32.

6. Klein R, Klein BE, Moss SE, Davis MD, DeMets DL. Glycosylated hemoglobin predicts the incidence and progression of diabetic retinopathy. JAMA 1988;260:2864-71.

7. The Diabetes Control and Complications Trial Research Group. The effect of intensive treatment of diabetes on the development and progression of long-term complications in insulin-dependent diabetes mellitus. N Engl J Med 1993;329:977-86.

8. Intensive blood-glucose control with sulphonylureas or insulin compared with conventional treatment and risk of complications in patients with type 2 diabetes (UKPDS 33). UK Prospective Diabetes Study (UKPDS) Group [see comments]. Lancet 1998;352:837-53.

9. Matthews DR, Stratton IM, Aldington SJ, Holman RR, Kohner EM. Risks of progression of retinopathy and vision loss related to tight blood pressure control in type 2 diabetes mellitus: UKPDS 69. Arch Ophthalmol 2004;122:1631-40.

10. Tight blood pressure control and risk of macrovascular and microvascular complications in type 2 diabetes: UKPDS 38. UK Prospective Diabetes Study Group. BMJ 1998;317:703-13.

11. Hecke MV, Dekker JM, Nijpels G, Moll AC, Heine RJ, Bouter LM, et al. Inflammation and endothelial dysfunction are associated with retinopathy: the Hoorn Study. Diabetologia 2005;48:1300-6.

12. Meleth AD, Agron E, Chan CC, Reed GF, Arora K, Byrnes G, et al. Serum inflammatory markers in diabetic retinopathy. Invest Ophthalmol Vis Sci 2005:46:4295-301.

13. Klein BE, Moss SE, Klein R, Surawicz TS. The Wisconsin Epidemiologic Study of Diabetic Retinopathy. XIII. Relationship of serum cholesterol to retinopathy and hard exudate. Ophthalmology 1991;98:1261-5.

14. Chew EY, Klein ML, Ferris FL III, Remaley NA, Murphy RP, Chantry K, et al. Association of elevated serum lipid levels with retinal hard exudate in diabetic retinopathy. Early Treatment Diabetic Retinopathy Study (ETDRS) Report 22. Arch Ophthalmol 1996;114:1079-84

15. Keech A, Simes RJ, Barter P, Best J, Scott R, Taskinen MR, et al. Effects of long-term fenofibrate therapy on cardiovascular events in 9795 people with type 2 diabetes mellitus (the FIELD study): randomised controlled trial. Lancet 2005;366:1849-61.

16. Zhang L, Krzentowski G, Albert A, Lefebvre PJ. Risk of developing retinopathy in Diabetes Control and Complications Trial type 1 diabetic patients with good or poor metabolic control. Diabetes Care 2001;24:1275-9.

17. Chaturvedi N, Sjoelie AK, Porta M, Aldington SJ, Fuller JH, Songini $M$, et al.; EURODIAB Prospective Complications Study. Markers of insulin resistance are strong risk factors for retinopathy incidence in type 1 diabetes. Diabetes Care 2001;24:284-9.

18. Henricsson M, Nystrom L, Blohme G, Ostman J, Kullberg C, Svensson M, et al. The incidence of retinopathy 10 years after diagnosis in young adult people with diabetes: results from the nationwide population-based Diabetes Incidence Study in Sweden (DISS). Diabetes Care 2003:26:349-54.

19. Keen $H$, Lee ET, Russell D, Miki E, Bennett PH, Lu M. The appearance of retinopathy and progression to proliferative retinopathy: the WHO Multinational Study of Vascular Disease in Diabetes. Diabetologia 2001;44(suppl 2):S22-30.

20. Effect of intensive blood-glucose control with metformin on complications in overweight patients with type 2 diabetes (UKPDS 34). UK Prospective Diabetes Study (UKPDS) Group [see comments]. Lancet 1998;352:854-65.
21. Wong $T Y$, Klein R, Islam FM, Cotch MF, Folsom AR, Klein BE, et al. Diabetic retinopathy in a multi-ethnic cohort in the United States. Am J Ophthalmol 2006; 141:446-55.

22. Klein R, Sharrett AR, Klein BE, Moss SE, Folsom AR, Wong TY, et al.; ARIC Group. The association of atherosclerosis, vascular risk factors, and retinopathy in adults with diabetes: the atherosclerosis risk in communities study. Ophthalmology 2002;109:1225-34.

23. Harris MI, Klein R, Cowie CC, Rowland M, Byrd Holt DD. Is the risk of diabetic retinopathy greater in non-Hispanic blacks and Mexican Americans than in non-Hispanic whites with type 2 diabetes? A U.S. population study. Diabetes Care 1998;21:1230-5.

24. Haffner SM, Fong D, Stern MP, Pugh JA, Hazuda HP, Patterson JK, et al. Diabetic retinopathy in Mexican Americans and non-Hispanic whites. Diabetes 1988;37:878-84.

25. Haffner SM, Hazuda HP, Stern MP. Effect of socioeconomic status on hyperglycaemia and retinopathy levels in Mexican Americans with NIDDM. Diabetes Care 1989;12:128-34.

26. Wong TY, Rosamond W, Chang PP, Couper DJ, Sharrett AR, Hubbard LD, et al. Retinopathy and risk of congestive heart failure. JAMA 2005;293:63-9.

27. Klein R, Klein BE, Moss SE. Epidemiology of proliferative diabetic retinopathy. Diabetes Care 1992;15:1875-91.

28. Moss SE, Klein R, Klein BE, Wong TY. Retinal vascular changes and 20-year incidence of lower extremity amputations in a cohort with diabetes. Arch Intern Med 2003;163:2505-10.

29. Klein BE, Klein R, McBride PE, Cruickshanks KJ, Palta M, Knudtson MD, et al. Cardiovascular disease, mortality, and retinal microvascular characteristics in type 1 diabetes: Wisconsin epidemiologic study of diabetic retinopathy. Arch Intern Med 2004; 164:1917-24.

30. Klein R, Klein BE, Moss SE, Cruickshanks KJ. Association of ocular disease and mortality in a diabetic population. Arch Ophthalmol 1999;117:1487-95.

31. Klein R, Klein BE, Moss SE. The relation of systemic hypertension to changes in the retinal vasculature: the Beaver Dam Eye Study. Trans Am Ophthalmol Soc 1997;95:32948.

32. Cugati S, Cikamatana L, Wang JJ, Kifley A, Liew G, Mitchell $P$. Five-year incidence and progression of vascular retinopathy in persons without diabetes: the Blue Mountains Eye Study. Eye 2005;20(11):1239-45.

33. Yu T, Mitchell P, Berry G, Li W, Wang JJ. Retinopathy in older persons without diabetes and its relationship to hypertension. Arch Ophthalmol 1998;116:83-9.

34. Wong TY, Barr EL, Tapp RJ, Harper CA, Taylor HR, Zimmet $P Z$, et al. Retinopathy in persons with impaired glucose metabolism: the Australian Diabetes Obesity and Lifestyle (AusDiab) study. Am J Ophthalmol 2005;140:1157-9.

35. Wong TY, Mohamed Q, Klein R, Couper DJ. Do retinopathy signs in non-diabetic individuals predict the subsequent risk of diabetes? Br J Ophthalmol 2006;90:301-3.

36. Garner A. Histopathology of diabetic retinopathy in man. Eye 1993;7:250-3.

37. Wong TY, Klein R, Sharrett AR, Schmidt MI, Pankow JS, Couper DJ, et al.; ARIC Investigators. Retinal arteriolar narrowing and risk of diabetes mellitus in middle-aged persons. JAMA 2002;287:2528-33.

38. Wong TY, Shankar A, Klein R, Klein BE, Hubbard LD. Retinal arteriolar narrowing, hypertension, and subsequent risk of diabetes mellitus. Arch Intern Med 2005;165:1060-5.

39. Ikram MK, Janssen JA, Roos AM, Rietveld I, Witteman JC, Breteler MM, et al. Retinal vessel diameters and risk of impaired fasting glucose or diabetes: the Rotterdam study. Diabetes 2006; 55:506-10.

40. Ikram MK, de Jong FJ, Van Dijk EJ, Prins ND, Hofman A, Breteler MM, et al. Retinal vessel diameters and cerebral small vessel disease: the Rotterdam Scan Study. Brain 2006;129:182-8.

41. Falck A, Laatikainen L. Retinal vasodilation and hyperglycaemia in diabetic children and adolescents. Acta Ophthalmol Scand 1995;73:119-24. 
42. Caballero AE. Metabolic and vascular abnormalities in subjects at risk for type 2 diabetes: the early start of a dangerous situation. Arch Med Res 2005;36:241-9.

43. Ikram MK, de Jong FJ, Vingerling JR, Witteman JC, Hofman A, Breteler MM, et al. Are retinal arteriolar or venular diameters associated with markers for cardiovascular disorders? The Rotterdam Study. Invest Ophthalmol Vis Sci 2004;45:2129-34.

44. Klein R, Klein BE, Knudtson MD, Wong TY, Tsai MY. Are inflammatory factors related to retinal vessel caliber? The Beaver Dam Eye Study. Arch Ophthalmol 2006;124:87-94.

45. Wong TY, Islam FM, Klein R, Klein BE, Cotch MF, Castro C, et al. Retinal vascular caliber, cardiovascular risk factors, and inflammation: the multi-ethnic study of atherosclerosis (MESA). Invest Ophthalmol Vis Sci 2006;47:2341-50.

46. Wong TY, Duncan BB, Golden SH, Klein R, Couper DJ, Klein BE, et al. Associations between the metabolic syndrome and retinal microvascular signs: the Atherosclerosis Risk In Communities study. Invest Ophthalmol Vis Sci 2004;45:2949-54.

47. Wang JJ, Taylor B, Wong TY, Chua B, Rochtchina E, Klein R, et al. Retinal vessel diameters and obesity: a populationbased study in older persons. Obesity (Silver Spring) 2006; 14:206-14

48. Cheung N, Saw SM, Islam FM, Rogers SL, Shankar A, de Haseth K, et al. Body mass index and retinal vascular caliber in children. Obesity (Silver Spring) 2007;15(1):209-15.

49. Nguyen TT, Wong TY. Retinal vascular manifestations of metabolic disorders. Trends Endocrinol Metab 2006;17:262-8.

50. Wong TY, Kamineni A, Klein R, Sharrett AR, Klein BE, Siscovick DS, et al. Quantitative retinal venular caliber and risk of cardiovascular disease in older persons: the cardiovascular health study. Arch Intern Med 2006;166:2388-94.

51. Wang JJ, Liew G, Wong TY, Smith W, Klein R, Leeder SR, et al. Retinal vascular caliber and the risk of coronary heart disease-related mortality. Heart 2006;92(11):1583-7.

52. Ikram MK, de Jong FJ, Bos MJ, Vingerling JR, Hofman A, Koudstaal PJ, et al. Retinal vessel diameters and risk of stroke: the Rotterdam Study. Neurology 2006;66:1339-43.

53. Wong TY, Klein R, Couper DJ, Cooper LS, Shahar E, Hubbard LD, et al. Retinal microvascular abnormalities and incident stroke: the Atherosclerosis Risk in Communities Study. Lancet 2001;358:1134-40.

54. Wong TY, Klein R, Sharrett AR, Duncan BB, Couper DJ, Tielsch JM, et al. Retinal arteriolar narrowing and risk of coronary heart disease in men and women. The Atherosclerosis Risk in Communities Study. JAMA 2002;287:1153-9.

55. Gunn M. Ophthalmoscopic evidence of (1) arterial changes associated with chronic renal diseases, and (2) of increased arterial tension. Trans Ophthalmol Soc UK 1892;12:124-5.

56. Wong TY, Mitchell P. Hypertensive retinopathy. N Engl J Med 2004;351:2310-7.

57. Mitchell P, Cheung N, de Haseth K, Wong TY. Blood pressure and retinal arterial narrowing in children. 2007. [unpublished work]

58. Klein R, Klein BE, Moss SE, Wang Q. Hypertension and retinopathy, arteriolar narrowing, and arteriovenous nicking in a population. Arch Ophthalmol 1994;112:92-8.

59. Wong TY, Klein R, Duncan BB, Nieto FJ, Klein BE, Couper DJ, et al. Racial differences in the prevalence of hypertensive retinopathy. Hypertension 2003;41:1086-91.

60. Wong TY, Coresh J, Klein R, Muntner P, Couper DJ, Sharrett $A R$, et al. Retinal microvascular abnormalities and renal dysfunction: the atherosclerosis risk in communities study. J Am Soc Nephrol 2004;15:2469-76.

61. Wong TY, Klein R, Sharrett AR, Nieto FJ, Boland LL, Couper DJ, et al. Retinal microvascular abnormalities and cognitive impairment in middle-aged persons: the Atherosclerosis Risk in Communities Study. Stroke 2002;33:1487-92.

62. Edwards MS, Wilson DB, Craven TE, Stafford J, Fried LF, Wong TY, et al. Associations between retinal microvascular abnormalities and declining renal function in the elderly population: the Cardiovascular Health Study. Am J Kidney Dis 2005;46:214-24
63. Wong TY, Klein R, Sharrett AR, Manolio TA, Hubbard LD, Marino EK, et al. The prevalence and risk factors of retinal microvascular abnormalities in older persons: The Cardiovascular Health Study. Ophthalmology 2003;110:658-66.

64. Wong TY, Klein R, Sharrett AR, Couper DJ, Klein BE, Liao DP, et al.; ARIC Investigators. Atheroslerosis Risk in Communities Study. Cerebral white matter lesions, retinopathy, and incident clinical stroke. JAMA 2002;288:67-74.

65. Wong TY, Rosamond W, Chang PP, Couper DJ, Sharrett AR, Hubbard LD, et al. Retinopathy and risk of congestive heart failure. JAMA 2005;293:63-9.

66. Mitchell P, Wang JJ, Wong TY, Smith W, Klein R, Leeder SR. Retinal microvascular signs and risk of stroke and stroke mortality. Neurology 2005;65:1005-9.

67. Wong TY, Klein R, Nieto FJ, Klein BE, Sharrett AR, Meuer SM, et al. Retinal microvascular abnormalities and 10-year cardiovascular mortality: a population-based case-control study. Ophthalmology 2003;110:933-40.

68. Sharrett AR, Hubbard LD, Cooper LS, Sorlie PD, Brothers RJ, Nieto FJ, et al. Retinal arteriolar diameters and elevated blood pressure: the Atherosclerosis Risk in Communities Study. Am J Epidemiol 1999;150:263-70.

69. Wong TY, Hubbard LD, Klein R, Marino EK, Kronmal R, Sharrett $A R$, et al. Retinal microvascular abnormalities and blood pressure in older people: the Cardiovascular Health Study. Br J Ophthalmol 2002;86:1007-13.

70. Tso MO, Jampol LM. Pathophysiology of hypertensive retinopathy. Ophthalmology 1982;89:1132-45.

71. Wong TY, Klein R, Sharrett AR, Duncan BB, Couper DJ, Klein $B E$, et al.; Atherosclerosis Risk in Communities Study. Retinal arteriolar diameter and risk for hypertension. Ann Intern Med 2004; 140:248-55

72. Smith W, Wang JJ, Wong TY, Rochtchina E, Klein R, Leeder $\mathrm{SR}$, et al. Retinal arteriolar narrowing is associated with 5year incident severe hypertension: the Blue Mountains Eye Study. Hypertension 2004;44:442-7.

73. Duncan BB, Wong TY, Tyroler HA, Davis CE, Fuchs FD. Hypertensive retinopathy and incident coronary heart disease in high-risk men. Br J Ophthalmol 2002;86:1002-6.

74. Klein R, Klein BE, Moss SE, Wang Q. Hypertension and retinopathy, arteriolar narrowing, and arteriovenous nicking in a population. Arch Ophthalmol 1994;112:92-8.

75. Wang JJ, Mitchell P, Leung H, Rochtchina E, Wong TY, Klein R. Hypertensive retinal vessel wall signs in a general older population: the Blue Mountains Eye Study. Hypertension 2003; $42: 534-41$.

76. Hubbard LD, Brothers RJ, King WN, Clegg LX, Klein R, Cooper LS, et al. Methods for evaluation of retinal microvascular abnormalities associated with hypertension/sclerosis in the Atherosclerosis Risk in Communities Study. Ophthalmology 1999;106:2269-80.

77. Kawasaki R, Wang JJ, Rochtchina E, Taylor B, Wong TY, Tominaga $\mathrm{M}$, et al. Cardiovascular risk factors and retinal microvascular signs in an adult Japanese population: the Funagata Study. Ophthalmology 2006;113:1378-84.

78. Klein R, Sharrett AR, Klein BE, Chambless LE, Cooper LS, Hubbard LD, et al. Are retinal arteriolar abnormalities related to atherosclerosis? The Atherosclerosis Risk in Communities Study. Arterioscler Thromb Vasc Biol 2000;20:1644-50.

79. Cooper LS, Wong TY, Klein R, Sharrett AR, Bryan RN, Hubbard LD, et al. Retinal microvascular abnormalities and MRIdefined subclinical cerebral infarction: the Atherosclerosis Risk in Communities Study. Stroke 2006;37:82-6.

80. Liao D, Wong TY, Klein R, Jones D, Hubbard L, Sharrett AR. Relationship Between Carotid Artery Stiffness and Retinal Arteriolar Narrowing in Healthy Middle-Aged Persons. Stroke 2004;35(4):837-42.

81. Wong TY, Knudtson MD, Klein BE, Klein R, Hubbard LD. Estrogen replacement therapy and retinal vascular caliber. Ophthalmology 2005;112:553-8.

82. Wong TY, Knudtson MD, Klein BE, Klein R, Hubbard LD. Medication use and retinal vessel diameters. Am J Ophthalmol 2005; 139:373-5. 
83. Liew G, Mitchell P, Leeder SR, Smith W, Wong TY, Wang JJ. Regular aspirin use and retinal microvascular signs: the Blue Mountains Eye Study. J Hypertens 2006;24:1329-35.

84. Wong TY, Shankar A, Klein R, Klein BE, Hubbard LD. Prospective cohort study of retinal vessel diameters and risk of hypertension. BMJ 2004;329:79.

85. Ikram MK, Witteman JC, Vingerling JR, Breteler MM, Hofman A, de Jong PT. Retinal vessel diameters and risk of hypertension: the Rotterdam Study. Hypertension 2006;47:189-94.

86. Liew G, Wong TY, Mitchell P, Wang JJ. Are narrower or wider retinal venules associated with incident hypertension? Hypertension 2006;48:e10.

87. Ikram MK, Witteman JC, Vingerling JR, Breteler MM, Hofman A, de Jong PT. Response to Are narrower or wider retinal venules associated with incident hypertension? Hypertension 2006 [Epub ahead of print].

88. Xing $C$, Klein BE, Klein R, Jun G, Lee KE, lyengar SK. Genome-wide linkage study of retinal vessel diameters in the Beaver Dam Eye Study. Hypertension 2006:47:797-802.

89. Taarnhoj NC, Larsen M, Sander B, Kyvik KO, Kessel L, Hougaard JL, et al. Heritability of retinal vessel diameters and blood pressure: a twin study. Invest Ophthalmol Vis Sci 2006; 47:3539-44.

90. Lee KE, Klein BE, Klein R, Wong TY. Changes in refraction over 10 years in an adult population: the Beaver Dam Eye study. Invest Ophthalmol Vis Sci 2002;43:2566-71.

91. van Leiden HA, Dekker JM, Moll AC, Nijpels G, Heine RJ, Bouter LM, et al. Blood pressure, lipids, and obesity are associated with retinopathy: the Hoorn study. Diabetes Care 2002;25:1320-5.

92. van Leiden HA, Dekker JM, Moll AC, Nijpels G, Heine RJ, Bouter LM, et al. Risk factors for incident retinopathy in a diabetic and nondiabetic population: the Hoorn study. Arch Ophthalmol 2003;121:245-51.

93. Van Hecke MV, Dekker JM, Nijpels G, Moll AC, Van Leiden HA, Heine RJ, et al.; Hoorn Study. et al. Retinopathy is associated with cardiovascular and all-cause mortality in both diabetic and nondiabetic subjects: the Hoorn study. Diabetes Care 2003;26:2958.
94. Barr EL, Wong TY, Tapp RJ, Harper CA, Zimmet PZ, Atkins R, et al.; AusDiab Steering Committee. Is peripheral neuropathy associated with retinopathy and albuminuria in individuals with impaired glucose metabolism? The 1999-2000 AusDiab. Diabetes Care 2006;29:1114-6.

95. Rema M, Mohan V, Deepa R, Ravikumar R; Chennai Urban Rural Epidemiology Study-2. Association of carotid intimamedia thickness and arterial stiffness with diabetic retinopathy: the Chennai Urban Rural Epidemiology Study (CURES-2) 38. Diabetes Care 2004;27:1962-7.

96. Hoogeveen EK, Kostense PJ, Eysink PE, Polak BC, Beks PJ, Jakobs $\mathrm{C}$, et al. Hyperhomocysteinemia is associated with the presence of retinopathy in type 2 diabetes mellitus: the Hoorn study. Arch Intern Med 2000;160:2984-90.

97. Alamouti B, Funk J. Retinal thickness decreases with age: an OCT study. Br J Ophthalmol 2003;87:899-901.

98. van Hecke MV, Dekker JM, Nijpels G, Stolk RP, Henry RM, Heine RJ, et al. Are retinal microvascular abnormalities associated with large artery endothelial dysfunction and intimamedia thickness? The Hoorn Study. Clin Sci (Lond) 2006;110:597-604.

99. Wong TY, Shankar A, Klein R, Klein BE. Retinal vessel diameters and the incidence of gross proteinuria and renal insufficiency in people with type 1 diabetes. Diabetes 2004; $53: 179-84$

100. Klein R, Klein BE, Moss SE, Wong TY, Sharrett AR. Retinal vascular caliber in persons with type 2 diabetes: The Wisconsin Epidemiological Study of Diabetic Retinopathy: XX. Ophthalmology 2006;113(9):1488-98.

\section{Endereço para correspondência:}

Jie Jin Wang

Centre for Vision Research

Department of Ophthalmology, University of Sydney

Westmead Hospital, Hawkesbury Rd

Westmead, NSW Australia, 2145

Fax: (61 2) 9845-8345

E-mail: jiejin_wang@wmi.usyd.edu.au 